\title{
ON SYMPTOMS FOLLOWING TICK-BITES IN MAN.
}

\author{
By GEORGE H. F. NUTTALL, F.R.S.
}

The interesting Note by Dr Sant' Anna, which precedes this paper, leads me to record some observations of a somewhat similar nature to those he has reported. My information is derived from three letters received from Africa, and from Dr Hindle.

The first letter, dated 2 October, 1909, was communicated to me by $\mathrm{Mr}$ W. F. Cooper, B.A., having been received by him from Dr J. W. Smith. The latter, at Mr Cooper's request, made on my behalf, had written to Dr G. E. Turner, of Johannesburg, and in response to his enquiries regarding the reputed effects of bont-tick ( $A$ mblyomma hebraeum) bites on man, received a letter from Dr Turner in which the latter states the following:

"Certain ticks, more particularly those found on the veld of the East Coast of Natal and Cape Colony, are liable, if they bite human beings, to set up a condition which might be suitably described as a form of tick fever. The symptoms commence with a rise in temperature, headache, or a dirty tongue, and later, pain and swelling in the femoral glands. It sometimes happens that the local lesions caused by the bite of the tick are only just noticeable, and might easily be overlooked, or, if noticed, be mistaken for an ordinary flea-bite, while the general symptoms are well marked. At the end of from 24-48 hours, however, one frequently obtains an account of a kind of bleb over the bite, and some watery material being squeezed out, after which a small sore is formed. It is generally fresh arrivals to the East Coast who become infected. Dr Campbell, of Durban, tells me that persons down in that part of the country are to a great extent immune; consequently, it is 
visitors and sailors who have been allowed on shore who are the most common victims. The severity of the disease varies considerably. There are generally several days during which the patient has a headache and high temperature, with painful and swollen glands, and in some cases the latter suppurate; but even where the symptoms are mild, and the glands subside without pus-formation, the effect on the general health is most depressing, it being often several weeks before the person affected feels really well. Patients of this class, if they travel, are very liable to be quarantined by the Health Authorities as Plague suspects.

It must be understood that the disease is entirely distinct from the form of tick fever produced by the bites of the large tick, Ornithodorus moubata, in which swelling of the glands is not a noticeable feature. I might add that on one occasion the 'Raylau Castle' came in from East London with five firemen who had temperature, dirty tongues, and enlarged glands, and the boat was put in quarantine for 24 bours pending bacteriological examination,- - they were all 'tick fever'.'

The second letter, dated 8 March, 1910, was written to me by Mr C. W. Howard, Government Entomologist, Lourenço Marques. It was not written with any idea of publication, but the writer has kindly consented to allow me to make use of it. Mr Howard writes:

"There have been several cases of fever contracted in Lourenço Marques recently, about which I should like to obtain your opinion. The fever always follows the bites of larval ticks which are picked up in a certain place just outside of the town where cattle are allowed to graze.

The case which first came to my notice was that of a lady, Mrs While out walking one Sunday, in the vicinity mentioned, she picked up a few ticks, larvae of Boophilus annulatus decoloratus, although at the time she gave little attention to the matter. Exactly eight days after this Mrs - came down with a very high fever. There was no clinical thermometer at hand but the fever must have gone as high as $104^{\circ} \mathrm{C}$. She had to go to bed for three days, but the remainder of the time she was unable to move about much. This high fever lasted four days, disappeared for about a day and then returned for a day. The other symptoms were severe depression, violent headache, severe backache in the region of the base of the spine, an inclination to nausea, loss of appetite, and swelling in the glands of the groin on the right side, the tick-bite being on the right hip. At the same 
time, the place where the tick had fastened developed into a large sore, highly inflamed and swollen, and eventually produced a core like a boil. From the first there was a small opening from which exuded a colourless liquid, but at the end pus was found for a week or more. To make sure of the diagnosis a physician was consulted, a man who has had several years' practice here. He declared it unmistakeably a tick-bite and prescribed a corrosive sublimate wash, and an ointment of Peruvian balsam and iodoform. Blood-smears showed the blood to be normal.

As I stated above, the ticks in question were larvae of $B$. annulatus decoloratus. A short time before, a herd of cattle grazing on the area where the ticks were picked up, contained several animals in which our Veterinary Surgeon found Spirochaeta theileri. The ticks found on these cattle include also Rhipicephalus evertsi and Amblyomma hebraeum, but $B$. annulatus decoloratus is by far the commonest, the other two being comparatively rare. Do you think there is a possibility that the Spirochaeta might be transmitted from the cattle to man?

At the time of her illness Mrs - had been in South Africa only 12 weeks. She had never before had fever of any sort, nor has she had it since. The infection occurred in November, a non-malarial and non-mosquito month here. She was living in a house very thoroughly mosquito-proofed and in a part of the town where Anopheles are extremely rare. So it cannot be considered as a case of malaria.

Some little time before this, the wife of a Transvaal official from Pretoria was visiting in Lourenço Marques, and in the same place picked up some ticks, four of which succeeded in attaching themselves. On her return to Pretoria, and in exactly eight days after picking up the ticks, she came down with fever. In her case, the fever seemed to come on alternating days and also during alternating weeks, extending in all over a month. The tick-bites produced large sores. Severe depression and extreme headache accompanied the fever. This lady also had never been exposed to mosquito bites, and her visit here was during July when no Anopheles were about.

Since that time I have heard of four other cases of fever following tick-bites, all of them showing similar symptoms to those of Mrs I am also told that in the vicinity of Grahamstown there is a place where the ticks always produce fever.

Apparently, it is only the one species of tick which produces the fever, for a few days ago Mrs - again picked up some larval ticks in a field where some goats often feed. In spite of her anxious endeavour 
seven succeeded in fastening themselves, but now (fifteen days afterwards) no fever has yet developed. This time the larvae were apparently those of Amblyomma hebraeum ${ }^{1 .}$."

In a subsequent letter, dated $11 \mathrm{June}, 1910, \mathrm{Mr}$ Howard writes :

"You mention the fact of persons long resident in a locality becoming immune to the tick-bites. I have noticed that here. It is always visitors or new arrivals who are affected.

At the present time I myself seem to be immune. Some years ago, soon after coming to Africa, I made a journey to Northern Zululand and was there bitten by larval ticks in the grass. One bite, just below the left knee, developed into a large sore, causing severe lameness for some weeks. I, however, did not, at the time, notice fever, only slight indisposition."

Dr E. Hindle, who is at present working in the Quick Laboratory, informs me that he and Dr Breinl suffered from the effects of the bites of Amblyomma hebraeum larvae whilst experimenting with these ticks at the Runcorn Research Laboratories, near Liverpool. The ticks were received in 1908 from Mr C. P. Lounsbury, Government Entomologist for Cape Colony; they were infected with Heartwater and were used for experiments on goats. Whilst transferring the ticks to a goat some of them escaped and attacked the experimenters. The ticks always attached themselves about the scrotum or navel. Although they produced no local lesions, both gentlemen, after about a week, suffered from slight fever, accompanied by headache and general depression. The inguinal glands became enlarged. In one case the gland attained the size of a walnut, and it was so tender as to render walking painful. The general symptoms subsided after a few days, but the glands remained swollen for some weeks, although they were not painful after the first few days. Dr Hindle was subsequently bitten by these ticks, but there was no recurrence of the symptoms above described, this apparently indicating an acquired immunity to the effects of the bites.

That untoward effects occasionally follow the bites of Argasid and Ixodid ticks has been recorded by me elsewhere ${ }^{2}$; these effects are, however, not to be confused with the subsequent development of a specific

1 The absence of any after-effects on this occasion may have been due to acquired immunity. G. H. F.N.

${ }^{2}$ Nuttall (1899), Johns Hopkins Hospital Reports, vIII. 42; (1908) Journ. Roy. Inst. Publ. Health, xvi. 14; (1908) Ticks, Part.I. pp. 81 et seq.; (1911) Ticks, Part II. p. 313 (in press, see regarding the effects of Ixodes ricinus bites). 
and recognized disease in the man or animal attacked by the tick. The Note by Dr Sant' Anna and the letters I have quoted point to a fairly definite train of symptoms following the attacks of certain ticks, and it appears justified, at least provisionally, to give to the condition the name of "tick-bite fever." The effects may ultimately prove to be due to either a toxin emanating from the tick or to a specific virus. We can scarcely refer to it as "tick fever," for this name has already been applied to African relapsing fever and Spotted Fever of the Rocky Mountains in man, and to the various diseases in animals due to Spirochaeta, Piroplasma, Nuttallia and Theileria. The name "tick fever" has, therefore, lost all significance, and should be dropped from our nomenclature. 